\title{
Integrity Education of University Students from the Perspective of Ideological and Political Theory
}

\author{
Duo Wang \\ School of Politics, Xi'an University, Xi'an Shanxi 710065
}

Keywords: Ideology and politics; Theoretical perspective; University students; Integrity education

\begin{abstract}
Ideological and political education is a social practice activity that social or social group imposes a purposeful, planned, organized influence to its members with a certain ideological ideas, political views, moral norms to make them meet a certain social requirements of the ideology and morality. It is also the basis of lifelong learning of many subjects in the university of China. Ideological and political education and integrity education of university students is the same, that is to say, the basic work of integrity education culture in university is based on the perspective of ideological and political theory. The basic multi-combination education mode can be realized by strengthening the training and education of integrity education on university students by ideological and political education teachers, improving the mode of education and giving a full play to the teaching practice of university students' incorruptible education.
\end{abstract}

\section{Introduction}

The theory education of ideological and political education and the integrity education of university students are all important for the construction of qualified talents for the socialist. From the perspective of creating channels for the ideological and moral education in university, integrity education has a better relevance and effectiveness, which is actively pursued by the majority of educators. The awareness of analyzing the existing problems in ideological and political education, and finding the importance of the construction of integrity culture on the social development and university students to adapt to society and employment process is the foundation to carry out high efficient ideological and political education and integrity education.

\section{The Development Background of Construction of Ideological and Political Education Theory in Colleges and Universities}

In the process of ideological and political education and theoretical development in colleges and universities, the work of integrity education in China has gone through a process. The pertinence and effectiveness of the integrity education is advancing with the political development. At first, the integrity education of university students has not been taken seriously. Later, on the basis of the reform of the new teaching system, people realized that the combination of the ideological and political education theory course and the integrity education of university students could form a higher conformity in the connotation and let the integrity deeply rooted in the minds of university students before they work, which can play a better role in promoting integrity education of the next generation.

It has a long history for the school launching its own political theory and ideological and political education, especially for the university, as the university students are a group of adults without a lot of social experience, but they have a complete autonomy and civil capacity. Therefore, for the ideological and political education and integrity education of university students, we must make a lot of effort in the process of scientifically and systematically preparing the system of integrity education and education planning from the reality and seeking truth from facts.

Corruption is in fact related to the life of students, it should be divided into two to look at educational corruption. On the one hand, some schools, some school leaders, some teachers do not have self-control, which has brought a shadow to the education sector. On the other hand, the educational concept of the student and the student's parents also led to the generation of corruption, 
because they desperately pursue the child's academic performance, while in the education method they put the teacher's attitude towards the child as a weight of whether their child can grow successfully. Therefore, many parents make use of the relations with the school to get the opportunity of the key schools, and make use of the relations with the head teacher, the relevant teacher to give their children overtime and other forms of remedial classes, the children's academic performance as the only way to develop children. Therefore, there is more chance of corruption in the education sector.

\section{The Inadequacy of Integrity Education in the Curriculum of Ideological and Political education in Colleges and Universities}

Speaking of corruption, people generally think of those who have the administrative power, administrative resources in the field, rarely look to the school or the education sector. However, from the media exposure of several cases, large to the national education poverty alleviation project bidding work, small to the school infrastructure construction, logistics, teaching materials, etc., corrupt elements are likely to find loopholes in schools. For educational corruption chaos, we have to attach great importance.

It has a long history for the school launching its own political theory and ideological and political education, especially for the university, as the university students are a group of adults without a lot of social experience, but they have a complete autonomy and civil capacity. Therefore, for the ideological and political education and integrity education of university students, we must make a lot of effort in the process of scientifically and systematically preparing the system of integrity education and education planning from the reality and seeking truth from facts.

Inadequate Understanding of the Main Channel of Ideological and Political Education Theory Course. From the media exposure of the case of education corruption, education procurement bid is the "hardest hit" of education corruption. This is because, in recent years, the procurement department of the education sector significantly is increased, some criminals see the "opportunity", even sail close to the wind. On the other hand, because the centralized power of the bid procurement in current education field, but the system is not perfect, regulatory procedures, standards, regulations are not yet sound. These educational processes can be combined with the anti-corruption education of university students, and the ideological and political theory course is consistent with the starting point of university students' anti-corruption education itself.

The understanding of integrity education and ideological and political education theory course is inadequate, for example, the consistency of ideological and political theory and integrity education in the work objectives, working methods and work path can not understand the connotation of the fit, so that the main channel base for university students' integrity education is very weak. Ideological and political education is the basis of university students' integrity education. If the teachers don't have a clear understanding of their own basic social roles, they may lack the basis and consciousness of the ideological and political theory course and lose the foundation of systematic and scientific standards for the integrity education, then the ideological and political theory of the main channel can not fully play a role. For the colleges and universities, there will be no basis for education at all levels, and will lose the fundamental effect of education. In other words, if understanding of the main channel of the ideological and political theory course is inadequate, then it can not be established on this basis for university students integrity education system of diversified development Therefore, the relationship between the ideological and political theory courses and integrity education of university students is very important.

The Impact of Social Bad thoughts on Integrity Education. At present, China's anti-corruption situation is very grim. In the process of the development of the new media era, due to the popularity of the network information and rapid impact, a variety of fragmented information may be able to a certain extent, can not completely plug the election, so money worship and money trading and other social bad ideas may be extensive existing around university students. From the perspective of the school, academic misconduct or university leaders using cadres and corruption has also occurred frequently. Many university teachers are affected by the bad social atmosphere, 
and have demands for the rights of money transactions and interests, which caused the degeneration of teachers' ethics. All these social bad thoughts indirectly or directly affect the healthy growth of university students' ideological and political morals, and it is not conducive to the effect of the integration education of university students on mistaken thoughts.

Ideological and Political Education in the Integrity of Education is Not Good. In the ideological and political education work, the current colleges and universities for the culture of clean and honest culture is not very strict norms, because there is no scientific planning educational effect and educational content. Therefore, the ideological and political education in the integrity of education, from the content and form as well as to the organizational arrangements, because there is no scientific planning teaching content and teaching effect. So there is no reasonable organization and implementation of the program, it is impossible to ideological and political work of the theoretical education courses and integrity education curriculum teaching effect idealized. And the content of the highly effective political theory education course is more, including the outline of the modern history of China, including the basic principles of Marxist philosophy, including the ideological and political moral education, including the legal basis, including Mao Zedong Thought, including the East and West situation And political many of these courses in the integrity of education, because the content is not particularly well-developed education methods, therefore, there is no way to do with the teaching and complement each other and support, it is because of the lack of a clear division of education. In the process of organizing civil education in the process of repeated crossings often exist, wasting the exchange of human and material resources, a waste of student time.

\section{The Basic Mode of Integrity Education in the Theoretical Course of Ideological and Political Education in Colleges and Universities}

The CPC Central Committee and the State Council on increasing the ideological and political education of university students put forward a lot of opinions, especially in the integrity of university students education, that university students are the hope of future countries and national pillars, so the ideological and political education in university students continue to strengthen and In the process of improvement, the ideological quality of university students can only be improved, so as to make more contributions to the socialist construction of China's science. The awareness and accomplishment of university students' honest and clean education is an important aspect to enhance the ideological and political quality. In the process of building a integrity education in our country has played a fundamental role is from the source to carry out integrity education and integrity of governance guarantee.

Highlight the Main Channel role of the Ideological and Political Education Theory. Adhere to the basic perspective of university students adhere to the mass line, under the leadership of the Chinese Communist Party to build and develop ideological and political education theory courses to ensure that the integrity of education in the ideological and political education courses in the main channel role, so that colleges and universities to achieve educational goals The inevitable distribution. Student teaching is to rely on the basis of teaching and student needs, focus on improving the educational methods and educational content, you can ensure that students in the ideological and political education courses to achieve a relatively good teaching effect. The Role of the Main Channel of the Independent Commission Against Corruption and Ideological and Political Education. We must adhere to the implementation of the integrity of education as the main body, correct self-thinking, establish a correct outlook on life and world view. Through the ideological and political education courses to help university students solve ideological and life problems, to help students achieve a comprehensive development, so that educators and students to strengthen exchanges, the use of full interaction to complete the role of the main channel.

Scientific Planning of Integrity Education in Ideological and Political Theory. Ideological and political education is the primary content of the construction of spiritual civilization in China and one of the main ways to solve social contradictions and problems. Ideological and political education is very important and very difficult to do, especially in the market economy conditions, 
China's ideological and political work there is a relatively weak situation, it is not suited to the requirements of modern social development. There are many reasons for the lack of ideological and political work, but one of the important reasons is that we have neglected personality education and training for a long time. I think that personality education is the basis of ideological and political education, without this foundation, ideological and political education is like a rootless duckweed, always drifting in the human mind and can not go deep.

On the problems of honest and clean education in the ideological and political theory course in colleges and universities. The application of flip - flop mode in the education of clean government can help to strengthen the enthusiasm of both teachers and students, improve the effect of ideological and political education and improve the effectiveness of clean government construction. In the ideological and political theory courses for university students to implement clean and honest education has a natural advantage; to carry out the campus clean and honest culture, full participation in the construction of clean government culture.

To Increase the Integrity of the Quality of Teachers Giving Ideological and Political Education. The ideological and political theory teachers in colleges and universities strengthen the research of ideological and political theory education methods, enhance the discipline construction and enhance the vitality and vitality of teaching. How to strengthen the ideological and political theory of education research is the ideological and political theory education and discipline construction of the top priority, we must first pay attention to the ideological and political theory of the educational function of the study, that is to improve people's ideological and moral quality, , Deepen the study of Marxism and the theory of ideology and politics. Secondly, we should pay attention to the study of the method of educating people in the internalization of ideological and political theory, that is, from the aspects of educational methods, means, ways and so on, how to strengthen the scientific theory and spirit of armed, guide and shape the people's integrity education literacy research. For the integrity of Marxism and Mao Zedong Thought under the influence of integrity education in the new century will have some new problems, for these new problems, teachers should learn in a timely manner, the specific method of education, otherwise it is likely due to rigid The effectiveness of education.

To Actively Improve the Ideological and Political Theory of Teaching Methods. The ideological and political theory course is a compulsory course for university students. Under the vision of cultivating the core values of socialism, it is necessary to realize the ultimate goal of the pertinence and effectiveness of ideological and political education in the fields of educational content, educational methods, educational mode On the constant innovation. This paper attempts to explore the use of new media platform, the historical knowledge into the ideological and political theory course teaching, seeking to solve the ideological and political theory of teaching effectiveness of teaching problems. The course of ideological and political theory is the main channel and main position of ideological and political education for university students. It is one of the compulsory courses for every college student. It is a socialist cause for cultivating moral, intellectual and physical development.

In the process of teacher's normal teaching and theoretical training, we should pay attention to the contents of the training of integrity education, so that teachers can understand how integrity education should teach, enhance their own awareness of integrity education, and contribute to the theoretical level of incorruptible education.

Organization of college teachers to carry out various forms of social practice, teachers and students through the study and practice of social understanding of the people, to understand the integrity of education teaching case, the use of these fresh and real teaching cases are often the most convincing. Students will also help the local discipline inspection departments to make some work.

Integrity education work, in a variety of academic exchanges and teaching exchanges, should also be developed as the main method of integrity education. In the specific implementation process, you can carry out fresh teaching case teaching, the use of video teaching, the use of discussion group teaching and learning research teaching concept, refused to empty teaching methods using a variety of teaching methods, brainstorming, the use of open class or practice class and micro-class 
teaching methods, to implement the integrity education of university students.

Conclusion: In contemporary China due to the rapid development of multimedia technology, the information that people got is very complex, so integrity education of university students has become a top priority. Establishment of the atmosphere of integrity education inside and outside the school, and clever infiltration of integrity education into the students 'daily behavior habits and learning the content of culture can improve students' ability to resist social bad thoughts. To achieve better results, the development of integrity education of university students should be with the classroom teaching. The students' community activities and the countryside activities, as well as the social practice of students should be combined with the socialist concept of honor and disgrace in the ideological and political education, so that students can understand the law with a healthy lifestyle and legal literacy, and can recognize what a great influence that corruption can bring for a country or a nation.

\section{Acknowledgements}

Fund Project:

1. Shaanxi Provincial Education Science 13th Five-Year Plan 2016 Annual Topic: A Study on the Basic Strategies of College Students' Ideological and Political Education from the Perspective of "Supply Side" Reform （Subject number : SGH16H211)

2. 2016 Xi'an Industrial University President Fund Project: Aesthetic Education and the All - round Development of College Students (Subject number : XAGDXJJ15030)

\section{References}

[1] Lu Dong. A study on the moral education about promoting the harmonious development of students' moral character[D]. Hebei Normal University, 2016.

[2] Haolin Liu. A study on the effectiveness of Ideological and political education of university students from the perspective of reception theory[D]. Liaoning Normal University, 2014.

[3] Qiyou Wang, Dongjie Zhang, Liping Jia. Research on the innovation of ideological and political education of university students from the perspective of cooperative theory[J]. The Party Building and Ideological Education in Schools, 2013, (23): 13-14.

[4] Feng Yu. The bottleneck and Countermeasures of contemporary university students' interpersonal communication from the perspective of Ideological and Political Education[D]. Jilin University of Finance and Economics, 2013.

[5] Cuiyun Jiang. Research on the innovation of Ideological and political education of university students from the perspective of positive psychology[D]. Central South University, 2012.

[6] Yi Yang. The modern sense of Di zi gui in university students' ideological and political education[D].Nanjing University of Aeronautics and Astronautics, 2012.

[7] Yongping Zeng. A study on the effectiveness of Ideological and political education of university students from the perspective of spiritual needs[D]. Guangxi Normal University, 2011.

[8] Aiping Zhang. An analysis of ideological and political education of university students from the perspective of learning theory[J]. Xuexiao Dangjian Yu Sixiang Jiaoyu, 2010, (34): 69-70.

[9] Yan Li. The study of university student ideological and political education from perspective of need theory[D]. Liaoning Normal University, 2010.

[10] Yu Wang. A study of ideological and political education of university students from the perspective of harmonious society[D]. Daqing Petroleum University, 2010.

[11]Zhengkun Wang, Changming Mao, Kongli Liu. Ideological and political education of university students from the perspective of university culture[J]. Journal of Shandong Youth Administrative Cadres College, 2009, (05): 38-40.

[12] Huaiyu Liu. Innovation of ideological and political work of university students from the perspective of harmonious cultural construction[J]. Journal of Yangzhou University (Higher Education Study Edition), 2008, (02): 46-49. 